\title{
Prevalence and Patterns of Sexting Among Ethnic Minority Urban High School Students
}

\author{
Melissa Fleschler Peskin, PhD, Christine M. Markham, PhD, Robert C. Addy, PhD, \\ Ross Shegog, PhD, Melanie Thiel, MPH, and Susan R. Tortolero, PhD
}

\begin{abstract}
Although sexting among U.S. youth has received much popular media attention, there are only limited data on its prevalence among ethnic minority youth. This study, therefore, specifically examined the prevalence and patterns of sexting (sending and/or receiving a nude or semi-nude picture/video or a sexual text-only message) among a sample of black and Hispanic youth. Data from 1,034 tenth graders from a large, urban school district in southeast Texas were used to calculate the prevalence of sexting by gender-race/ethnicity. Overlap among sexting behaviors was also examined. Electronic surveys were administered via an audio-computerassisted self-interview on laptop computers. Prevalence estimates were obtained, and chi-square analyses were conducted to compare the distribution of sexting behaviors by gender-race/ethnicity subgroups. More than $20 \%$ of students reported sending either a nude or semi-nude picture/video or a sexual text-only message (jointly referred to as a "sext"), and more than 30\% reported receiving a sext. Sexts were also frequently shared with unintended recipients. Black males and females reported similar prevalence estimates for sexting behaviors. However, they were more likely than Hispanic males to participate in some sexting behaviors. Hispanic females reported the lowest estimates for sexting behaviors for all gender-race/ethnicity subgroups. Many youth who sent or received a nude or semi-nude picture/video were also likely to have sent or received sexual text-only messages. The results of this study indicate that sexting is prevalent among ethnic minority youth. However, more research is needed to understand the specific context and circumstances around which sexting occurs in this population.
\end{abstract}

\section{Introduction}

S EXTING-USING TECHNOlogy to CREATE, send, and receive sexually explicit photos, videos, and/or text-only messages - is a relatively new trend among youth, which has garnered much popular media attention recently. ${ }^{1-4}$ Estimates of prevalence for sexting with nude or semi-nude pictures or videos (e.g., a teen sending a picture of her naked breasts) vary substantially: from $2.5 \%$ to $27.6 \%$ for senders / creators and from $7.0 \%$ to $34.5 \%$ for recipients, ${ }^{5-13}$ depending on how sexting is defined and the age range of the sample used. There may be legal consequences for youth who send or receive nude or semi-nude pictures or videos, but the condition under which arrest occurs varies. ${ }^{14}$ In a recent national study of youth sexting cases reported to law enforcement, more than $60 \%$ of cases that involved adults (e.g., a youth produced a sexual image of himself or herself and sent it to an adult) resulted in an arrest. However, almost $20 \%$ of youth who engaged in sexting without any apparent intent to harm (e.g., "experimental" cases) were also arrested. ${ }^{14}$ Although a principal concern of sexting is the transmission of sexual media that are potentially illegal, ${ }^{5}$ teens also send and receive sexually suggestive text-only messages (e.g., a teen texting a message to another teen asking for sex). In a recent report, almost $40 \%$ of young people reported sending such messages, and almost $50 \%$ reported receiving them. ${ }^{9}$

Aside from the potential legal consequences of sexting, more studies are needed to determine if sexting impacts other behaviors and health outcomes among youth and adults and, if so, what is the direction of the impact. Some researchers have speculated that forwarding sexual media to unintended recipients could have an adverse psychosocial impact on the individual shown in the picture or video, ${ }^{7}$ which is supported by a recent cross-sectional report linking sexting with suicidal ideation. ${ }^{15}$ Furthermore, other reports have found that youth who appear in, create, receive, or are asked to send media with sexual images feel upset, embarrassed, or bothered. ${ }^{5,12}$ Sexting may also promote inappropriate peer norms 
surrounding expected dating or sexual behavior, ${ }^{16}$ which could lead to sexual risk behaviors. ${ }^{17}$ For example, in their large study of multi-ethnic youth, Temple et al. ${ }^{12}$ found that youth who engaged in sexting were more likely to have begun dating and to have had sex. Because Temple et al. used cross-sectional data, the temporality of their findings is unclear. In a study of predominantly Hispanic young women, however, Ferguson ${ }^{11}$ found no association between sexting and most high-risk sexual behaviors.

Although more research is needed to determine the effects of sexting, the first step in any public health inquiry is to understand the scope and prevalence of a potential health problem. Some data exist on the prevalence of sexting among youth in general. However, prevalence data for ethnic minority youth specifically are scarce. ${ }^{11,12}$ In a recent national report including more than 2,000 young people, black and Hispanic youth were more likely to report cell phone texting and computer use, respectively, than White youth. ${ }^{18}$ Studies of sexting among racial/ethnic minority youth are thus warranted. In this study, we specifically examined the prevalence and patterns of sexting among a sample of black and Hispanic high school students from a large, urban school district in southeast Texas.

\section{Materials and Methods}

\section{Study design, participants, and procedures}

Data were collected from tenth graders who participated in the final follow-up assessment of an HIV, STD, and pregnancy prevention randomized controlled trial during fall 2009 and spring 2010. ${ }^{19}$ Students were originally recruited into the trial while they were in the seventh grade from 15 middle schools in a large, urban school district in southeast Texas. Research staff recruited seventh graders from classes in which the majority of students were enrolled (either physical education or homeroom). Parental consent forms were obtained by $60 \%$ of seventh graders $(n=2,256)$; affirmative consents were returned by more than $80 \%$ of these students $(n=1,873)$. Of consented students, $93 \%$ completed a baseline survey $(n=1,742)$. The majority of the sample was eligible for free/reduced lunch, an indicator of economic disadvantage. Of students who completed the baseline survey, $71 \%$ also completed the tenth-grade survey $(n=1,233)$. Student assent was obtained from all participants.

Surveys were administered via an audio-computer-assisted self-interview on laptop computers by trained data collectors. Sexting items asked if the participant had ever sent, posted, received, and/or shared nude or semi-nude pictures or videos and sexually suggestive text-only messages. ${ }^{16}$ Internet/cell phone usage items were adapted from an existing survey. ${ }^{20}$ Institutional review boards at The University of Texas Health Science Center and the Centers for Disease Control and Prevention and the school district's Office of Research and Accountability approved the study.

\section{Statistical analysis}

All statistical analyses were conducted with SAS 9.2 (SAS Institute, Inc., Cary, NC). Descriptive statistics were obtained. Chi-square analyses with pairwise comparisons were used to determine the distribution of sexting behaviors by gender-race/ethnicity subgroups. Prevalence estimates of the proportion of students involved in different combinations of sexting behaviors were also calculated. Alpha level was set at 0.05 . Due to small numbers, students of a race/ethnicity other than Hispanic or black were excluded $(n=137)$. Students who were missing data on sexting $(n=28)$ and on Internet/cell phone use $(n=34)$ were also excluded. Thus, 1,034 students were included in the analyses.

\section{Results}

More than $60 \%$ of students were female, $43 \%$ black, and $57 \%$ Hispanic. The mean age was $16.3(S D=0.68)$ years; more than $98 \%$ of students were under the age of 18 . The vast majority of participants reported using the Internet and a cell phone (for talking and/or texting) during the past week (Table 1). Hispanic males reported significantly less cell phone use than Hispanic and black females, and less Internet use than black females $(p<0.05)$. There were no other significant differences in Internet or cell phone use among the sub-groups.

More than $20 \%$ of students reported sending either a nude or semi-nude picture or video or a text-only message (jointly referred to as a "sext"), and more than $30 \%$ reported receiving a sext. Fewer students reported posting sexts online. Almost $10 \%$ reported sharing sexts with someone other than the originally intended recipient; almost $20 \%$ reported having had sexts shared with them. Across almost all sexting behaviors, black males and females had similar participation rates. Black males and females, however, were more likely than Hispanic males to participate in some sexting behaviors. Among gender-race/ethnicity subgroups, Hispanic females had the lowest participation across all sexting behaviors (Table 2).

Fifty percent of sexting youth reported sending or receiving nude or semi-nude pictures or videos and sexually suggestive text-only messages. Conversely, almost half of

Table 1. Sample Demographics $(N=1,034)$

\begin{tabular}{lcc}
\hline & $n$ & $\%$ \\
\hline Sex & & \\
Male & 387 & 37.4 \\
Female & 647 & 62.6 \\
Race/Ethnicity & & \\
Black & 441 & 42.7 \\
Hispanic & 593 & 57.4 \\
Weekly Internet use & & \\
Did not use & 85 & 8.2 \\
$<1$ hour & 155 & 15.0 \\
1-2 hours & 165 & 16.0 \\
3-5 hours & 227 & 22.0 \\
6-10 hours & 145 & 14.0 \\
10+ hours & 257 & 24.9 \\
Weekly cell phone use & & \\
Did not use & 133 & 12.9 \\
$<1$ hour & 68 & 6.6 \\
1-2 hours & 62 & 6.0 \\
3-5 hours & 95 & 9.2 \\
6-10 hours & 108 & 10.4 \\
10+ hours & 568 & 54.9 \\
Student age, years, & $16.34(0.68)$ & \\
$\quad$ mean (SD) [Range] & & $14.60,19.37]$ \\
\hline
\end{tabular}


Table 2. Percentage of Black and Hispanic Youth Engaged in Sexting via the Internet or Cell Phone

\begin{tabular}{|c|c|c|c|c|c|}
\hline $\begin{array}{l}\text { Nude or semi-nude } \\
\text { pictures/videos }\end{array}$ & $\begin{array}{l}\text { Sent a nude } \\
\text { or semi-nude } \\
\text { picture/video } \\
\text { (of yourself) to } \\
\text { someone } \\
\text { (via e-mail, } \\
\text { cell phone, etc.) }\end{array}$ & $\begin{array}{l}\text { Posted a nude } \\
\text { or semi-nude } \\
\text { picture/video } \\
\text { (of yourself) } \\
\text { online (like on } \\
\text { MySpace, Facebook, } \\
\text { in a blog, etc.) }\end{array}$ & $\begin{array}{l}\text { Received a nude } \\
\text { or semi-nude } \\
\text { picture/video from } \\
\text { someone (of } \\
\text { himself/herself) }\end{array}$ & $\begin{array}{l}\text { Shared a nude } \\
\text { or semi-nude } \\
\text { picture/video with } \\
\text { someone other than } \\
\text { the one(s) it was } \\
\text { originally meant for }\end{array}$ & $\begin{array}{l}\text { Had a nude } \\
\text { or semi-nude } \\
\text { picture/video } \\
\text { (originally meant } \\
\text { to be private) } \\
\text { shared with me }\end{array}$ \\
\hline Total $(N=1,034)$ & 21.2 & 4.3 & 31.0 & 8.8 & 18.2 \\
\hline $\begin{array}{l}\text { By race/gender } \\
\text { Black female }(n=290) \\
\text { Hispanic female }(n=357) \\
\text { Black male }(n=151) \\
\text { Hispanic male }(n=236)\end{array}$ & $\begin{array}{l}26.9^{\mathrm{a}} \\
16.8^{\mathrm{b}} \\
23.2^{\mathrm{b}} \\
19.5^{\mathrm{b}}\end{array}$ & $\begin{array}{l}4.8^{\mathrm{b}} \\
2.5^{\mathrm{b}} \\
8.6^{\mathrm{a}} \\
3.4^{\mathrm{b}}\end{array}$ & $\begin{array}{l}36.2^{\mathrm{a}} \\
23.0^{\mathrm{b}} \\
36.4^{\mathrm{a}} \\
33.1^{\mathrm{a}}\end{array}$ & $\begin{array}{c}7.6 \\
6.4^{\mathrm{a}} \\
12.6^{\mathrm{b}} \\
11.4^{\mathrm{b}}\end{array}$ & $\begin{array}{l}17.9^{\mathrm{a}} \\
11.8^{\mathrm{d}} \\
30.5^{\mathrm{b}} \\
20.3^{\mathrm{a}, \mathrm{c}}\end{array}$ \\
\hline $\begin{array}{l}\text { Sexually suggestive } \\
\text { messages }\end{array}$ & $\begin{array}{l}\text { Sent a sexually } \\
\text { suggestive } \\
\text { message to } \\
\text { someone (e-mail, } \\
\text { IM, text, etc.) }\end{array}$ & $\begin{array}{l}\text { Posted a sexually } \\
\text { suggestive message } \\
\text { to someone's } \\
\text { online profile } \\
\text { (MySpace, } \\
\text { Facebook, etc.) }\end{array}$ & $\begin{array}{l}\text { Received a } \\
\text { sexually suggestive } \\
\text { message from } \\
\text { someone (e-mail, } \\
\text { IM, text, etc.) }\end{array}$ & $\begin{array}{l}\text { Shared a sexually } \\
\text { suggestive message } \\
\text { with someone other } \\
\text { than the one(s) it } \\
\text { was originally } \\
\text { meant for }\end{array}$ & $\begin{array}{l}\text { Had a sexually } \\
\text { suggestive message } \\
\text { (originally meant } \\
\text { to be private) } \\
\text { shared with me }\end{array}$ \\
\hline Total $(N=1,034)$ & 24.8 & 5.4 & 31.5 & 7.7 & 15.5 \\
\hline $\begin{array}{l}\text { By race/gender } \\
\text { Black female }(n=290) \\
\text { Hispanic female }(n=357) \\
\text { Black male }(n=151) \\
\text { Hispanic male }(n=236)\end{array}$ & $\begin{array}{l}30.7^{\mathrm{a}} \\
18.2^{\mathrm{b}} \\
29.1^{\mathrm{a}} \\
24.6\end{array}$ & $\begin{array}{l}5.9^{\mathrm{a}} \\
2.5^{\mathrm{b}} \\
7.3^{\mathrm{a}} \\
8.1^{\mathrm{a}}\end{array}$ & $\begin{array}{l}40.3^{\mathrm{a}} \\
26.9^{\mathrm{b}} \\
31.8^{\mathrm{b}} \\
27.5^{\mathrm{b}}\end{array}$ & $\begin{array}{r}8.6^{\mathrm{a}} \\
4.5^{\mathrm{b}} \\
11.3^{\mathrm{a}} \\
9.3^{\mathrm{a}}\end{array}$ & $\begin{array}{l}17.6^{\mathrm{a}} \\
11.8^{\mathrm{b}} \\
21.2^{\mathrm{a}} \\
14.8\end{array}$ \\
\hline
\end{tabular}

Note: Statistical significance is read within each vertical column. Estimates that are statistically different from one another at $p<0.05$ are indicated with different superscripts. Estimates with the same superscripts or those in which one estimate has a superscript and the other one does not are not statistically different.

"posters" reported transmitting only text-only messages. Most sexting youth reported either sending and receiving or only receiving nude or semi-nude pictures/videos or textonly messages. With respect to sharing sexts originally meant to be private, more than $50 \%$ of sexting youth reported being the recipient exclusively. However, one-third of sexting youth reported being the "sharer" and recipient of sexts originally meant to be private (Table 3).

\section{Discussion}

Among this sample of ethnic minority high school youth, we found that $21 \%$ had sent nude or semi-nude pictures or videos and that $31 \%$ had received such media. These estimates indicate that picture/video-based sexting is prevalent among ethnic minority youth, and they are similar to estimates from other studies conducted among various populations (e.g., White private high school students, large online teen sample, young Hispanic females, and a multi-ethnic school-based sample). ${ }^{7,9,11,12}$ In spite of this consistency among prevalence estimates, there is still substantial variation in the prevalence of sexting with nude or semi-nude pictures/videos reported in the literature. ${ }^{5,6,8}$ These discrepancies are most likely attributable to variation in study sample, measures, and methodology. For example, other studies limited their sample to predominantly households with landline phones ${ }^{5}$ or to youth with cell phones. ${ }^{8}$

Close to $25 \%$ and $32 \%$ of ethnic minority youth, respectively, reported sending and receiving sexually suggestive text-only messages. Fewer studies have examined the prev- alence of this behavior. ${ }^{9,10}$ While it is common for teens to obtain information about sex from their peers, ${ }^{21}$ the transmission of sexually suggestive content could promote the belief that sex is expected among the teens who exchange this content. $^{9,22}$ Furthermore, in a previous study, teens who viewed television content that portrayed "sexual talk" (e.g., discussions about sexual plans or behavior) were more likely to report sexual behavior. ${ }^{23}$ Those findings indicate the importance of understanding the implications of "sexual talk" as they relate to understanding the prevalence of sexually suggestive text-only messages transmitted among youth.

Almost $10 \%$ of ethnic minority youth had sent sexts to unintended recipients. Estimates from previous studies for this behavior range from 3\% among U.S. teens aged 13-19 years $^{24}$ to $25 \%$ among predominantly White private high school students. ${ }^{7}$ It is unclear, however, whether those estimates reflect the sharing of private media that were not meant to be shared. It is possible that these unplanned exchanges could have emotional consequences for the original sender, ${ }^{7}$ especially if that individual subsequently felt bullied. $^{25}$

Some studies have reported a greater tendency for females to be sext senders/creators ${ }^{24}$ and males to be recipients. ${ }^{6,7}$ This pattern did not emerge in this study. In fact, compared to the other gender-racial/ethnic subgroups, Hispanic females were less likely to engage in any sexting behavior. A similar pattern for sending sexual media was observed for Hispanic and black youth in a previous study. ${ }^{12}$ Studies suggest that "sexual talk" may be seen as disrespectful for Hispanic female youth, $^{26}$ which may help to explain these findings. 
Table 3. Percentage of Black and Hispanic Youth ${ }^{\text {a }}$ Engaged in Combinations of Sexting Behaviors

\begin{tabular}{|c|c|c|c|c|c|c|c|c|}
\hline & & \multicolumn{2}{|c|}{$\begin{array}{c}\text { Sent a nude or } \\
\text { semi-nude } \\
\text { picture/video } \\
\text { (of yourself) and/or } \\
\text { sexually suggestive } \\
\text { message to someone } \\
\text { (via e-mail, cell } \\
\text { phone, etc.) } \\
(n=319)\end{array}$} & \multicolumn{2}{|c|}{$\begin{array}{c}\text { Posted a nude } \\
\text { or semi-nude } \\
\text { picture/video } \\
\text { (of yourself) and/or } \\
\text { sexually suggestive } \\
\text { message online } \\
\text { (like on MySpace, } \\
\text { Facebook, in a } \\
\text { blog, etc.) }(n=82)\end{array}$} & $\begin{array}{c}\text { Received a nude } \\
\text { or semi-nude } \\
\text { picture/video from } \\
\text { someone (of } \\
\text { himself/herself) or } \\
\text { sexually suggestive } \\
\text { message from } \\
\text { someone }(n=422)\end{array}$ & $\begin{array}{l}\text { Shared a nude } \\
\text { or semi-nude } \\
\text { picture/video and/or } \\
\text { sexually suggestive } \\
\text { message with } \\
\text { someone other } \\
\text { than the one(s) it } \\
\text { was originally } \\
\text { meant for }(n=126)\end{array}$ & $\begin{array}{c}\text { Had a nude or } \\
\text { semi-nude } \\
\text { picture/video and/or } \\
\text { sexually suggestive } \\
\text { message (originally } \\
\text { meant to be private) } \\
\text { shared with me } \\
\quad(n=246)\end{array}$ \\
\hline $\begin{array}{l}\text { Nude or semi-r } \\
\text { picture/vide }\end{array}$ & $\begin{array}{l}\text { ade } \\
\text { only }\end{array}$ & \multicolumn{2}{|l|}{19.8} & \multicolumn{2}{|c|}{31.7} & 22.8 & 36.5 & 35.0 \\
\hline $\begin{array}{l}\text { Sexually sugge } \\
\text { message only }\end{array}$ & & \multicolumn{2}{|l|}{31.4} & \multicolumn{2}{|c|}{46.3} & 24.2 & 27.8 & 23.6 \\
\hline \multirow[t]{2}{*}{ Both } & \multicolumn{3}{|c|}{48.9} & \multicolumn{2}{|c|}{22.0} & 53.1 & 35.7 & 41.5 \\
\hline & \multicolumn{2}{|c|}{$\begin{array}{l}\text { Sent andlor } \\
\text { received a nude } \\
\text { or semi-nude } \\
\text { picture/video } \\
\text { (of yourself) (via } \\
\text { e-mail, cell phone, } \\
\text { etc.) }(n=366)\end{array}$} & $\begin{array}{r}\text { Se } \\
\text { recei } \\
\text { sugge } \\
\text { (via } \\
\text { phone, }\end{array}$ & $\begin{array}{l}\text { nt and } \\
\text { ved se } \\
\text { stive } n \\
\text { e-mail } \\
\text { etc.) }\end{array}$ & & & $\begin{array}{l}\text { Shared and/or had } \\
\text { shared with me a } \\
\text { nude or semi-nude } \\
\text { picture/video } \\
\text { originally meant } \\
\text { to be private }(n=214)\end{array}$ & $\begin{array}{c}\text { Shared andlor } \\
\text { had shared with } \\
\text { me a sexually } \\
\text { suggestive message } \\
\text { originally meant } \\
\text { to be private }(n=176)\end{array}$ \\
\hline Sent only & & \multicolumn{2}{|r|}{12.1} & \multicolumn{2}{|c|}{ Shared only } & 12.2 & 9.1 \\
\hline Received only & \multicolumn{2}{|r|}{40.2} & \multicolumn{2}{|r|}{31.0} & \multicolumn{2}{|c|}{$\begin{array}{l}\text { Had shared with } \\
\text { me only }\end{array}$} & 57.5 & 54.6 \\
\hline Both & \multicolumn{2}{|r|}{47.3} & \multicolumn{2}{|r|}{56.9} & \multicolumn{2}{|c|}{ Both } & 30.4 & 36.4 \\
\hline
\end{tabular}

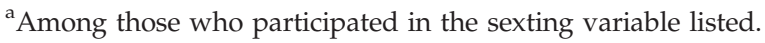

Additionally, black males and females were more likely to post and send, respectively, sexual media than Hispanic males. These results could potentially be explained by the findings from another study of ethnic minority youth in which the inverse association between unfavorable expectancies (i.e., getting a bad reputation) related to sex and intentions to have sex was found to be stronger in Hispanic youth than in black youth. ${ }^{27}$ In other words, Hispanic youth may be more likely than black youth to associate sex with negative consequences. Our findings could also be explained by the fact that black youth enter puberty earlier ${ }^{28}$ and are more likely to report first sex before age 13 compared with Hispanic youth. ${ }^{29}$ Still, for many other sexting behaviors, Hispanic males reported comparable levels to blacks. Future research should continue to examine the role of culture and race/ethnicity as it relates to sexting behaviors.

Finally, half of sexting youth had sent and received sexually suggestive text-only messages and nude or semi-nude pictures or videos. To our knowledge, this overlap in sexting behavior has not been previously reported. Furthermore, similar to another study, ${ }^{24}$ many sexting youth reported sending and receiving sexts. Although more research is needed to determine what, if any, adverse health sequelae are associated with sexting, the "dose" of youths' exposure can increase the likelihood of their engaging in a related risk behavior. For example, Collins et al. ${ }^{23}$ reported a dose-response relationship between sexual content on television and sexual initiation among youth.

This study has some limitations, which include the use of general screening questions about sexting and none about intent (e.g., for bullying, as a joke, in the context of a relationship) or whether images were perceived as pornography.
Additionally, although the school district from which students were sampled was representative of other large, urban school districts, care should be taken in generalizing these results. Because of the racial/ethnic composition of the sample, we were unable to compare sexting behaviors between ethnic minority and non-ethnic minority students. Future studies should use ethnically diverse samples to make such comparisons. Furthermore, there may be selection bias due to only $60 \%$ of students returning a parental consent form. This response rate, however, is typical of other school-based studies with low-income ${ }^{30}$ or minority youth. ${ }^{31}$ Additionally, students who did not respond to sexting questions were not examined. However, there were no significant differences by gender or race/ethnicity between students who did and those who did not respond to these questions. Lastly, it is possible that differences in the prevalence of cell phone and Internet use between Hispanic males and black females could have contributed to the higher estimates of some sexting behaviors among black females. Future analyses should control for Internet and cell phone use in their analyses (this was beyond the scope of the current study, which was to determine overall prevalence estimates). It should be noted, however, that Hispanic females, who reported the lowest prevalence of sexting behaviors, actually reported higher cell phone use than Hispanic males.

This study indicates that sexting is prevalent among ethnic minority youth, and is one of only a few studies to present sexting prevalence data in this understudied population. Additional studies are needed to determine the context and circumstances around which sexting occurs in this population. Furthermore, prospective analyses are needed to determine 
the association between sexting, sociodemographic factors, and behavioral and health outcomes.

\section{Acknowledgments}

This work was funded by the Centers for Disease Control and Prevention (CDC) (\#5U48DP000057) and the U.S. Department of Health and Human Services (HHS), Adolescent Family Life (90XF0036). The findings and conclusions in this report are those of the authors and do not necessarily represent the official position of the CDC or HHS. The study is registered at www.clinicaltrials.gov (\#U48/DP000057). The authors wish to thank Lionel Santibáñez for his editorial assistance. Data were presented, in part, at the 139th Annual Meeting and Exposition of the American Public Health Association, Washington, DC; October 29, 2011-November 2, 2011.

\section{Author Disclosure Statement}

No competing financial interests exist.

\section{References}

1. Caron C. Teen sexting linked to psychological distress. http://abcnews.go.com/Technology/teen-sexting-linkedpsychological-distress/story?id=14914700\#.UCGHvE38sWY (accessed Jul. 20, 2012).

2. Inbar M. "Sexting" bullying cited in teen's suicide. http:// today.msnbc.msn.com/id/34236377/ns/today-today_news/ t/sexting-bullying-cited-teens-suicide/\#.UCGIBU38sWY (accessed Jul. 20, 2012).

3. Celizic M. Her teen committed suicide over "sexting." http:// today.msnbc.msn.com/id/29546030/ns/today-parenting and_family/t/her-teen-committed-suicide-over-sexting/\#. UCGI8E38sWY (accessed Jul. 20, 2012).

4. Stephey MJ. Sexting. Top 10 buzzwords. The top 10 of everything in 2009. www.time.com/time/specials/packages/ article/0,28804,1945379_1944799_1944801,00.html (accessed Jul. 20, 2012).

5. Mitchell KJ, Finkelhor D, Jones LM, et al. Prevalence and characteristics of youth sexting: a national study. Pediatrics 2012; 129:13-20.

6. Hinduja S, Patchin JW. Sexting: a brief guide for educators and parents. Cyberbullying Research Center, 2010. www .cyberbulling.us (accessed Feb. 6, 2012).

7. Strassberg DS, McKinnon RK, Sustaíta MA, et al. Sexting by high school students: an exploratory and descriptive study. Archives of Sexual Behavior 2013; 42:15-21.

8. Lenhart A. Teens and sexting: how and why minor teens are sending sexually suggestive nude or nearly nude images via text messaging. Pew Internet \& American Life Project. Pew Research Center. http://pewinternet.com/ /media//Files/ Reports/2009/PIP_Teens_and_Sexting.pdf (accessed Jun. 28, 2012).

9. The National Campaign to Prevent Teen Pregnancy and Unplanned Pregnancy. Sex and tech results from a survey of teens and young adults. Washington, DC: Author, 2009.

10. The Associated Press and MTV. Executive summary: 2011 AP-MTV digital abuse study. www.athinline.org/pdfs/ MTV-AP_2011_Research_Study-Exec_Summary.pdf (accessed Jun. 28, 2012).

11. Ferguson CJ. Sexting behaviors among young Hispanic women: incidence and association with other high-risk sexual behaviors. The Psychiatric Quarterly 2011; 82:239-43.
12. Temple JR, Paul JA, van den Berg $P$, et al. Teen sexting and its association with sexual behaviors. Archives of Pediatrics \& Adolescent Medicine 2012; 1-6.

13. Dowdell EB, Burgess AW, Flores JR. Original research: online social networking patterns among adolescents, young adults, and sexual offenders. The American Journal of Nursing 2011; 111:28-36.

14. Wolak J, Finkelhor D, Mitchell KJ. How often are teens arrested for sexting? Data from a national sample of police cases. Pediatrics 2012; 129:4-12.

15. The Associated Press and MTV. 2009 AP-MTV digital abuse study - a thin line. www.athinline.org/MTV-AP_Digital_ Abuse_Study_Executive_Summary.pdf (accessed Feb. 6, 2012).

16. The National Campaign to Prevent Teen and Unplanned Pregnancy and Cosmogirl.com. Sex and tech: results from a survey of teens and young adults. www .thenationalcampaign.org/sextech/pdf/sextech_summary .pdf (accessed Feb. 6, 2012).

17. O'Donnell L, Myint-U A, O'Donnell CR, et al. Long-term influence of sexual norms and attitudes on timing of sexual initiation among urban minority youth. The Journal of School Health 2003; 73:68-75.

18. Rideout VJ, Foehr UG, Roberts DF. Generation $\mathrm{M}^{2}$ : media in the lives of 8- to 18-year-olds: a Kaiser Family Foundation study. www.kff.org/entmedia/upload/8010.pdf (accessed Feb. 6, 2012)

19. Markham CM, Tortolero SR, Peskin MF, et al. Sexual risk avoidance and sexual risk reduction interventions for middle school youth: a randomized controlled trial. Journal of Adolescent Health 2012; 50:279-88.

20. The San Jose Mercury News/Kaiser Family Foundation. Growing up wired: survey on youth and the Internet in the Silicon Valley. www.kff.org/entmedia/loader.cfm?url =/ commonspot/security/getfile.cfm\&PageID=14233 (accessed Oct. 26, 2012).

21. Reznik Y, Tebb K. Where do teens go to get the 411 on sexual health? A teen intern in clinical research with teens. The Permanente Journal 2008; 12:47-51.

22. Moreno MA, Vanderstoep A, Parks MR, et al. Reducing atrisk adolescents' display of risk behavior on a social networking web site: a randomized controlled pilot intervention trial. Archives of Pediatrics \& Adolescent Medicine 2009; 163:35-41.

23. Collins RL, Elliott MN, Berry $\mathrm{SH}$, et al. Watching sex on television predicts adolescent initiation of sexual behavior. Pediatrics 2004; 114:e280-9.

24. Cox Communications. Teen online and wireless safety survey: cyberbullying, sexting, and parental controls. Atlanta, GA: Cox Communications, National Center for Missing \& Exploited Children, and John Walsh, 2009.

25. Reijntjes A, Kamphuis JH, Prinzie P, et al. Peer victimization and internalizing problems in children: a meta-analysis of longitudinal studies. Child Abuse \& Neglect 2010; 34: 244-52.

26. Deardorff J, Tschann JM, Flores E. Sexual values among Latino youth: measurement development using a culturally based approach. Cultural Diversity \& Ethnic Minority Psychology 2008; 14:138-46.

27. Guilamo-Ramos V, Jaccard J, Dittus P, et al. Adolescent expectancies, parent-adolescent communication and intentions to have sexual intercourse among inner-city, middle school youth. Annals of Behavioral Medicine 2007; 34:56-66. 
28. Sun SS, Schubert CM, Chumlea WC, et al. National estimates of the timing of sexual maturation and racial differences among U.S. children. Pediatrics 2002; 110:911-9.

29. Eaton DK, Kann L, Kinchen S, et al. Youth risk behavior surveillance-United States, 2011. Morbidity \& Mortality Weekly Report. Surveillance Summaries. 2012; 61:1-162.

30. Esbensen FA, Melde C, Taylor TJ, et al. Active parental consent in school-based research: how much is enough and how do we get it? Evaluation Review 2008; 32:335-62.

31. Stein BD, Jaycox LH, Langley A, et al. Active parental consent for a school-based community violence screening: comparing distribution methods. The Journal of School Health 2007; 77:116-20.

Address correspondence to: Dr. Melissa Fleschler Peskin Center for Health Promotion and Prevention Research 7000 Fannin Street, Suite 2658

Houston, TX 77030

E-mail: Melissa.F.Peskin@uth.tmc.edu 